\title{
NEMZETKÖZI TÖREKVÉSEK A CSALÁDON BELÜLI ERŐSZAK ELLENI BÜNTETŐJOGI VÉDELEMRE - A TÁvCSŐ TÚlOLDALÁN: AUSZTRIA ÉS SZLOVÁKIA
}

\author{
International Efforts for the Criminal Law Protection Against \\ Domestic Violence - Looking on the Other Side: Austria and \\ Slovakia
}

\section{Garai Renáta ${ }^{12}$}

\begin{abstract}
Absztrakt: A tanulmány ismerteti a családon belüli erőszakot átfogóan szabályozó Isztambuli Egyezmény létrejöttét, majd a magyarországi büntetőjog történetében nóvumnak számító kapcsolati erőszak önálló bűncselekményi tényállását érinti. A szerző ezután nemzetközi kitekintés keretében két szomszédos ország, Ausztria és Szlovákia joganyagába és főbb családvédelmi törekvéseibe nyújt betekintést. A tanulmány a jogösszehasonlítások által arra kíván rámutatni, hogy az Isztambuli Egyezmény - és más fontos nemzetközi dokumentumok - alappillérét jelenthetik az egyes tagállamok büntetőjogi szabályozásának addig is, amíg az egyezmény aláirását még nem követte ratifikáció.
\end{abstract}

Kulcsszavak: család, gyermek, erőszak, új bűncselekmény

Abstract: The paper first describes how the Istanbul Convention, regulating domestic violence in a comprehensive manner, came into existence; afterwards we briefly examine the statutory provision of relationship violence, a novelty in the history of Hungarian criminal law. The author then gives an insight into the legislation and main family

1 Károli Gáspár Református Egyetem Állam- és Jogtudományi Doktori Iskola, PhD hallgató; Országos Kriminológiai Intézet, tudományos munkatárs. E-mail címe: garai@okri.hu

A szerző további munkásságát lásd a Magyar Tudományos Művek Tára oldalán: https: //m2.mtmt.hu/gui2/?type=authors\&mode=browse\&sel=10060801

${ }^{2}$ A publikáció Az Innovációs és Technológiai Minisztérium ÚNKP-19-3-I. kódszámú Új

Nemzeti Kiválóság Programjának szakmai támogatásával készült. 
protection efforts of two neighbouring countries, Austria and Slovakia, in an international perspective. With this international comparison, the paper wishes to point out that the Istanbul Convention - together with other significant international documents - can be the cornerstone of the criminal law legislation of member states, pending ratification of the Convention.

Keywords: family, child, violence, new criminal law provisions

\section{BEVEZETÉS}

Jelen tanulmány érintőlegesen Magyarország, majd Ausztria és Szlovákia vonatkozó joganyagába és főbb családvédelmi törekvéseibe nyújt betekintést, amelyek mindegyikére nagy hatást gyakorolt az Isztambuli Egyezmény. Ausztria 2011 májusában írta alá, majd 2014 augusztusában a nemzeti jogába át is ültette ezt a nemzetközi dokumentumot, míg Szlovákiában - Magyarországhoz hasonlóan - a ratifikáció még várat magára, de ennek ellenére a családon belüli erőszak meglehetősen magas büntetési tételekkel, önálló bűncselekményként került szabályozásra.

A családon belüli erőszak jelenségével összefüggésben rövid visszatekintésként az Európa Tanács tevékenységének meghatározó szerepét említeném, hiszen vezető emberi jogi szervezetként számos kezdeményezést tudhat magáénak, ideértve az egész Európára kiterjedő kampányt is, amely a nőkkel szembeni erőszak elleni küzdelemre fókuszálva az erôszak valamennyi formáját elutasítja. Az egyes tagállamok nemzeti jelentései, tanulmányai és felmérései feltárták a probléma nagyságát, de különösen azt mutatták be, hogy az erre adott nemzeti válaszok mennyire sokszínűek Európában. A harmonizált jogi normák iránti igény és az átfogó szabályozás szükségessége nyilvánvalóvá vált annak biztosítása érdekében, hogy az áldozatok ugyanolyan szintű védelmet kaphassanak Európa valamennyi tagállamában. Mindezek érvényesülése érdekében 2008 decemberében szakértői ad hoc bizottságot (CAHVIO) hoztak létre, amely kilenc alkalommal tartott tanácskozása eredményeként 2010 decemberében lezárta, véglegesítette az Egyezmény szövegtervezetét, majd a Miniszteri Bizottság elfogadását követően Isztambulban nyitották meg aláirásra 2011. május 11-én; végül Andorra 2014. április 22-én kelt 10. ratifikációját 
követően 2014. augusztus 1-jén lépett hatályba. ${ }^{3}$ Az Európa Tanács nők elleni erőszak és a családon belüli erőszak megelőzéséről és felszámolásáról szóló Egyezménye egy komplex dokumentum a sértettek által már elszenvedett, vagy agresszióval fenyegetett magatartások ellen. Pillanatnyilag arról számolhatunk be, hogy 12 ország már aláírta az Isztambuli Egyezményt, de még nem ratifikálta (köztük Magyarország sem), ${ }^{4} 34$ ország viszont mindent megtett azért, hogy megerősítse, és hatályba is léptesse. ${ }^{5}$

Jelen tanulmány megjelenésekor - 2020. május - a COVID-19 világjárvány ismét előtérbe hozta a családon belüli erőszak témakörét. A koronavírus megjelenésének eredményeként a világ lakosságának harmada kijárási tilalom alá került, és ahol még ezt nem rendelték el, a szabad mozgást illetôen szigorú korlátozások léptek életbe, amelyek a családon belüli erőszak felerősödéséhez vezettek; vannak helyszínek, ahol 40-50\%-os emelkedésről számoltak be a szakértők. ${ }^{6}$ Az életmentés érdekében tett erőfeszítések okozta bezártság egy veszélyeztetett csoportot az átlagosnál is veszélyesebb helyzetbe sodort, mert az erőszak fokozódó megjelenése az elszigeteltségnek is tulajdonítható. A segélyvonalak hívásainak, valamint a segítségkérő sms és e-mail üzenetek száma nagymértékben emelkedett, illetve arra is felhívták a figyelmet világszerte, hogy sokan éppen a bántalmazó folyamatos jelenléte miatt nem tudnak még segítséget kérni sem. ${ }^{7}$ Ennélfogva a családon belüli erôszak eseteit nemzetközi viszonylatban vizsgálva a téma talán most aktuálisabb, mint valaha volt.

\footnotetext{
3 ISTANBUL CONVENTION ACTION AGAINST VIOLENCE AGAINST WOMEN AND DOMESTIC VIOLENCE

4 Örményország, Bulgária, Csehország, Magyarország, Írország, Lettország, Liechtenstein, Litvánia, Moldovai Köztársaság, Szlovák Köztársaság, Ukrajna, Egyesült Királyság

5 Albánia, Andorra, Ausztria, Belgium, Bosznia és Hercegovina, Horvátország, Ciprus, Dánia, Észtország, Finnország, Franciaország, Grúzia, Németország, Görögország, Izland, Írország, Olaszország, Luxemburg, Málta, Monaco, Montenegró, Hollandia, ÉszakMacedónia, Norvégia, Lengyelország, Portugália, Románia, San Marino, Szerbia, Szlovénia, Spanyolország, Svédország, Svájc, Törökország.

Chart of signatures and ratifications of Treaty 210 Council of Europe Convention on preventing and combating violence against women and domestic violence

${ }^{6}$ SZÉKELY HírMONDÓ, 2020.; DipPOLD ÁdÁM, 2020.

7 THE GUARDIAN, 2020.
} 


\section{MAgYARORSZÁG ZÁSZLAJA ALATT}

Magyarország területén számos erőfeszítés tapasztalható a családon belüli erőszak prevenciója és visszaszorítása, az esetleges mulasztások, valamint a tragédiákhoz vezető okok feltárása érdekében. A hozzátartozók sérelmére elkövetett bűncselekmények kommunikációja nemcsak a közelmúltban, hanem évek óta felerősödni látszik, melynek egyik mérföldköve a „győri kettős gyermekgyilkosság” volt. Az ennek hatására elrendelt vizsgálat eredményéről készült jelentésben ${ }^{8}$ az Igazságügyi Minisztérium nemcsak a büntető ügy (előzmények, fogva tartás időszaka, feltételes szabadságra bocsátás körülményei, szabadulást követő cselekmények) és a polgári ügy (házassági bontóper, a szülők megállapodása a közös szülői felügyeleti jogról, szülői felügyeleti jog megszüntetésére irányuló per) főbb sarokpontjait tárta fel, hanem konkrét javaslatokat és megtett intézkedéseket is tartalmazott. ' Az általam vizsgált ügyek tapasztalataival összhangban kiemelést érdemlőnek tartom a gyermekvédelmi jelzőrendszer működésének felülvizsgálatára irányuló kezdeményezést, emellett úgyszintén előremutató, hogy 2020 az áldozatsegítés éve Magyarországon, amely az Áldozatsegítő Központok kapacitásainak megduplázásában ölt testet. ${ }^{10}$ A COVID-19 világjárvány megelőzése és kezelése a kézirat lezárásánál természetesen minden mást felülírt, és az egyes szakterületek különböző súllyal értékelődnek, de a kényszerű együttlét okozta családi feszültségekre, és a gyermekek fokozott veszélyeztetésére már a koronavírus okozta veszélyhelyzet első idôszakában felfigyeltek a szakemberek, a hatóságok és az Országos Kríziskezelő Központ (rövidítve: OKIT) is; a konkrét hatás a későbbiekben lesz értékelhető.

A család fogalmához hozzátartozik a gyermek, így az ott megjelenő cselekmények kontextusában a kiskorúak prioritása nem kérdőjelezhető meg. Ezen a ponton válik nélkülözhetetlenné a gyermekvédelem, melynek feladatát Rácz Andrea a hátrányos helyzetűek, a veszélyeztetett vagy már egyébként is gyermekvédelmi gondoskodásban élő kiskorúak számára

\footnotetext{
${ }^{8}$ IGAZSÁGÜGYI MINISZTÉRIUM, 2019.

$9 \mathrm{Az}$ igazságügyi miniszter ezen túlmenően kezdeményezte a bírósági joggyakorlat felülvizsgálatát az élet elleni bűncselekmények esetében érvényesített középmérték szabályának büntetéskiszabás során való érvényesítése tekintetében, valamint a szülői felügyelet, a kapcsolattartás és a gyermekelhelyezés vonatkozásában egyaránt.

10 Forrás: https://www.kormany.hu/hu/igazsagugyi-miniszterium/hirek/a-gyori-kettosgyermekgyilkossagrol-keszult-jelentes
} 
történő társadalmi integráció elősegítésében látja, illetve a védelmi rendszert egyfajta korrekciós, kompenzáló és szükségletkielégitő intézményként is definiálja. ${ }^{11}$

A 2012. évi C. törvény (a továbbiakban: Btk.) a nemi élet szabadsága és a nemi erkölcs elleni búncselekményeket tartalmazó XIX. Fejezete, a gyermekek érdekét sértő és a család elleni bűncselekményekről szóló XX. Fejezete, továbbá a kapcsolati erôszak büntetőjogi tényállása is a nemzetközi dokumentumok rendelkezéseinek figyelembe vételével került megalkotásra, így a hatályos Btk. - más büntetőjogi tárgyú jogszabályokkal kiegészítve megfeleltethető a legfontosabb nemzetközi elvárásoknak. ${ }^{2}$ A Btk. 212/A. \a szerinti kapcsolati erôszak előzmény nélküli, önálló bűncselekményi tényállásának (1) bekezdése az emberi méltóságot súlyosan sértő, megalázó és erőszakos magatartásokat, valamint a gazdasági ellehetetlenítést is büntetni rendeli, ugyanakkor ezen új, a fizikai bántalmazás szintjét el nem érő elkövetési magatartások oly mértékben előrehozták a büntetőjogi védelmet, hogy ebben a körben a hatóság fellépésére csak magánindítvány előterjesztése esetén kerülhet sor. A (2) bekezdést vizsgálva megállapítható, hogy beépítette a jogalkotó a Btk.-ban másutt kétségtelenül szereplő, ám esetenként alacsonyabb büntetési tétellel fenyegetett magatartásokat (könnyű és súlyos testi sértés, tettleges becsületsértés, kényszerítés, személyi szabadság megsértése) ${ }^{13}$, viszont ezen cselekmények már fizikai bántalmazásban nyilvánulnak meg, éppen ezért hozzátartozók - mint speciális passzív alanyok - sérelmére elkövetés esetén az officialitás elve érvényesül. ${ }^{14}$ A teljes bűncselekményi tényálláson átívelő speciális többletkövetelmény a rendszeres elkövetés, amely a törvényhelyhez füzött indokolás, a több kötetes Új Btk. Kommentár ${ }^{15}$, illetve a Kúria iránymutatása ${ }^{16}$ alapján már legalább két elkövetés esetében is megállapítható. A törvényhelyhez füzött indokolás szerint a bûncselekmény különleges sértetti köre indokolta

${ }^{11}$ RÁCZ, 2016. 155. o.

12 Btk. 212/A \-ához füzött miniszteri indokolás.

13 Rendszeres (legalább kétszeri) elkövetés esetén a helyes minősítés kapcsolati erőszak, és három, illetve egy évtől öt évig terjedő szabadságvesztéssel büntetendő.

14 A bűncselekmény gyakorlati alkalmazása körében kiemelést érdemel a hozzátartozók közötti erőszak kezelésével összefüggő rendőrségi feladatok végrehajtásáról szóló 2/2018. (I.25.) ORKF utasítás, melynek kiadása az egységes végrehajtás érdekében történt, legfőbb célja, hogy Magyarország valamennyi megyéjében iránymutatásként szolgáljon a helyszíni intézkedések során.

15 LAJTÁR, 2013. 80. o.

16 17/2017. SZ. BÜNTETŐ ELVI HATÁROZAT. 
leginkább egy külön tényállás megalkotását, melynek jellemzője az elkövetéskori vagy korábbi együttélésből fakadó bizalom és az esetleges kiszolgáltatottság.

\section{CSALÁD- ÉS GYERMEKVÉDELEM A NEMZETKÖZI SZÍNTÉREN}

A jogösszehasonlító elemzések által megállapítható, hogy az EU tagállamok büntetőjogi beavatkozását illetően valamennyi ország kódexében megjelenik a hozzátartozók sérelmére elkövetett bűncselekmények speciális szankcionálása, azonban ezek jogalkotó általi beépítése különféle módon történt meg. A családon belüli erőszak cselekményei - főként a bűncselekmény helyszíne, illetve a sértett és az elkövető viszonya okán eltérőek a többi bűncselekménytípustól, melynek ellensúlyozására többféle megoldás kínálkozik. Az egyik lehetôség az egyes bűncselekményekhez kapcsolt minősített eseteken túlmenően a büntető törvénykönyv egészére generálisan kiható rendelkezéssel figyelembe venni a sértettet megalázó bánásmódot, a sértett életkorát, egészségi állapotát, betegségét vagy kiszolgáltatott helyzetét (például Románia, ahol egyébként mindezek mellett még külön tényállásban is megjelennek a „családtag ellen elkövetett bűncselekmények”); míg a másik esetben a családi viszonyokat csak bizonyos deliktumokhoz kapcsolt minősített eset jeleníti meg a speciális passzív alanyok tekintetében. Mindezek még hangsúlyosabbá tehetők azáltal, hogy önálló bűncselekményként jelenik meg a családon belüli erőszak (például Portugália, Spanyolország, Lengyelország, Szlovákia ${ }^{17}$ ), vagy választhatja a jogalkotó az utóbbi kettő vegyítését is (például Magyarország), melynél fogva nemcsak meghatározott bűncselekményekhez társít szigorúbb jogkövetkezményeket a hozzátartozója, nevelése, felügyelete, gondozása alatt álló, illetve a sértettel kapcsolatban fennálló egyéb hatalmai vagy befolyási viszonyával visszaélés esetére, hanem a családon belüli erőszak külön bűncselekményi szankcionálásáról is gondoskodik.

A gyermekvédelmet nemzetközi ernyő alatt vizsgálva felhívnám a figyelmet ehelyütt a máig legszélesebb körben elfogadott emberi jogi dokumentumként megszületett ENSZ Gyermekjogi Egyezményre, amely egyedülállóan helyezi fókuszba az életkort, és amelynek 1. cikkében megszületett a "globális gyermek” fogalma akként, hogy ,gyermek az a

17 53/2009. (V.6.) AB HATÁroZAT III.2.2. pont. 
személy, aki a tizennyolcadik életévét nem töltötte be, kivéve ha a reá alkalmazandó jogszabályok értelmében nagykorúságát már korábban eléri."

\subsection{AusZTRIA}

A Magyarországgal szomszédos Ausztriában ${ }^{18}$ is az írott jog alkotja elsődlegesen az osztrák jog forrásait, ennek megfelelően a szokásjog minimálisra korlátozódik. A legfelsőbb bíróságok ítélkezési gyakorlata fontos iránymutatásokat határoz meg, és kiemelt jelentősége sem kérdőjelezhetô meg, de a bíróságok által alkotott jog formálisan nem számít jogforrásnak. Az osztrák alkotmány szerint a nemzetközi jog általánosan elismert szabályai az osztrák szövetségi jog részét képezik, a nemzetközi szerződéseket pedig konkrét jogszabályokkal, vagy azok nélkül illesztik az osztrák jogrendszerbe. Az osztrák szövetségi alkotmánnyal összhangban a tartományokban (német elnevezés: Bundesländer) a szövetségi alkotmányjog mellett - egyfajta alárendelt viszonyban - az adott tartomány saját alkotmányjoga is érvényesül, ez azonban értelemszerűen nem ellenkezhet a szövetségi alkotmányjoggal; a szövetségi és a tartományi törvények között ugyanakkor főszabály szerint ez a rangsor nem áll fenn. ${ }^{19}$

2009. június 1. napjától új bűncselekménnyel bővült az Osztrák Büntető Törvénykönyv (német elnevezés: Strafgesetz̧uch, a továbbiakban rövidítve: StGB $)^{20}$, ezáltal az ismételten ugyanazon személy ellen elkövetett erôszakos cselekményeket súlyosabb büntetési tétellel rendelik büntetni. Az osztrák StGB nem a házasság és a család elleni, hanem a szabadság elleni bűncselekmények fejezetében tárgyalja az erőszak ezen formáját, továbbá ide építette be a jogalkotó többek között a személyi szabadság megsértését, az emberkereskedelmet, a zaklatást, és a távközlési, illetve számítógépes rendszer segítségével elkövetett folyamatos zaklatást is.

Az StGB 107.b. \-a a cselekmények folyamatosságát már a bűncselekmény nevében is hangsúlyozza, „folyamatos erőszak”-nak (német elnevezés: Fortgesetżte Gewaltausübung) nevesítve azon magatartásokat, ha az elkövető hosszabb ideje követi el a más személye elleni erőszakot. Adott deliktum ezen cselekményeket alapesetben legfeljebb három évig terjedő szabadságvesztéssel bünteti, mely tényállás lényegében a rendszerességre, vagyis a jogsértések ismétlődésére helyezi a hangsúlyt. 2016. január 1-jétől ez

\footnotetext{
18 Ausztria 1995. január 1. napján csatlakozott az Európai Unióhoz.

${ }^{19}$ European Justice. Ausztria.

${ }^{20}$ Forrás: https://www.jusline.at/gesetz/stgb/gesamt
} 
a definíció már magában foglalja nemcsak a testi, hanem pszichés bántalmazásokat egyaránt, e körbe vonva a személyi szabadság és a vagyon elleni sérelmeket is, valamint az adatvédelemmel összefüggő magatartásokat (például hozzáférés, nyilvánosságra hozatal). ${ }^{21}$ Minősített esetként rögzíti a törvény - és a magatartáshoz hat hónaptól öt évig terjedő szabadságvesztéssel fenyegetettséget társít - ha az elkövető beteg, kiskorú, védekezésre képtelen személy ellen követi el cselekményét, illetőleg ha a magatartás a sértett viselkedésének átfogó, teljes körű ellenőrzésére, autonóm életének jelentős korlátozására irányul. További minősített esetként jelenik meg a sértett szexuális önrendelkezésének és integritásának ismétlődő megsértése a fenti erőszak folyamatos alkalmazásának részeként (egytől tíz évig terjedő szabadságvesztés), ha a magatartás a keletkezett sérülések tekintetében súlyos és tartós következményekkel jár, továbbá ha az erőszakot több mint egy éve gyakorolják (öt évtől tizenöt évig terjedő szabadságvesztés), végül pedig ha a bủncselekmény halált okoz (ez esetben a büntetés tíz évtôl húsz évig terjedhet).

A magyar szabályozással ellentétben az StGB az egész tényállást szubszidiáriusnak tekinti azáltal, hogy megfogalmazza: az elkövető nem a fenti rendelkezések alapján büntetendő, amennyiben a cselekményt más rendelkezés ennél súlyosabb, szigorúbb büntetéssel fenyegeti. A szubszidiaritással összefüggésben vissza kell utalni arra, hogy a büntetés kiszabása során a bíróságnak mérlegelnie kell a súlyosító és enyhítő körülményeket, valamint figyelembe kell venni a büntetés és a bűncselekmény egyéb várható következményeinek az elkövető jövőbeni életére gyakorolhat hatásait is. Mindenekelőtt azt kell figyelembe venni, hogy az adott bűncselekmény milyen mértékben alapul az elkövető jogilag védett értékeket elutasító hozzáállásán vagy azok iránt közömbös maradt-e, és milyen mértékben tulajdonítható külső körülményeknek vagy motívumoknak, amelyek nyilvánvalóvá tehetik azt a jogilag védett értékkel társult személy számára. A tényálláshoz füzött kommentár kiemeli, hogy a kétszeres értékelés tilalmára tekintettel a bűncselekménynek a Btk. 107b. 』-a szerinti megítélésekor különös figyelmet érdemelnek a súlyosító tényezők, különösen azért, mivel ezen körülményt maga az StGB 107b. \-a már figyelembe vette. ${ }^{22}$

21 GREVIO FIRST COUNTRY REPORT AUSTRIA, 2016. 43. o.

${ }^{22}$ Forrás: https://www.jusline.at/gesetzeskommentare/456492181 
Gyermek- és családvédelmi aspektusból kiemelném, hogy az osztrák StGB házasság és család elleni bủncselekményi fejezetében egyebek mellett a többes házasságot vagy bejegyzett élettársi kapcsolatot, a tiltott örökbefogadást, a gyermekrablást, a tartási kötelezettség elmulasztását, az oktatás vagy felügyelet elhanyagolását tárgyalja. A következő fejezetben nyertek elhelyezést a szexuális bűncselekmények (így például kiskorúak pornográf ábrázolása, hatalmi viszonnyal való visszaélés, gyermekprostitúció, vérfertőzés), ahol a nemi erôszak és a szexuális kényszerítés mellett az osztrák jogalkotó külön szabályozza a kiskorúak ez irányú zaklatását a speciális sértetti kör súlyos zaklatásától. Az StGB 74. \-a szerinti értelmező rendelkezésből kitűnik, hogy a szövetségi törvény a kiskorúak vonatkozásában külön nevesíti a 14. életévüket be nem töltötteket (német elnevezés: unmündig), illetve azon személyeket, akik még nem érték el 18. életévüket (német elnevezés: minderjährig). Az StGB 206. \-a szerint alapesetben egytôl tíz évig terjedő szabadságvesztéssel büntetendő azon személy, aki 14 év alatti kiskorúval szexuális kapcsolatot létesít, vagy ennek megfelelő (ezzel egyenértékü) szexuális cselekményt végez. Szintén büntetendő, aki saját vagy harmadik személy nemi vágyának felkeltése vagy kielégítése érdekében kiskorú személyt más személlyel végzendő szexuális együttlétre vagy azzal egyenértékű cselekmény végzésére vagy tűrésére rábír. A minősített eseteket öttől tizenöt, illetve tíztől húsz évig terjedő vagy életfogytig tartó szabadságvesztéssel fenyegeti az osztrák jogalkotó, ha a cselekmény súlyos testi sérülést vagy a kiskorú terhességét eredményezi, figyelembe veszi a cselekmény huzamosabb időn át tartó jellegét vagy a megalázás különleges módját, legsúlyosabban pedig természetesen azt értékeli, ha a bűncselekmény a kiskorú halálát eredményezi.

A GREVIO értékelő országjelentése rámutatott arra, hogy az egyes régiókat illetően éles kontraszt mutatkozik a családon belüli erőszak, illetve az egyéb bűncselekmények áldozatai számára nyújtandó szolgáltatások eloszlása között. Így például, míg a kilenc osztrák tartomány (német elnevezés: Bundesland) erőszakvédelmi központjának mindegyike biztosítja az előírt követelményeket a családon belüli erőszak áldozatai érdekében, csak ötnek van szakirányú tanácsadási szolgáltatása a szexuális bűncselekmények sértettjei segítésére, de ez természetesen nem függetleníthető ezen szolgáltatások megfelelő és/vagy kellően hosszú távú finanszírozásától. ${ }^{23}$

23 GREVIO Baseline Evaluation RePOrT Austria, 2017. 31.o. 
Ausztriában a családtag sérelmére elkövetett testi, lelki vagy szexuális bűncselekmény, illetve az úgynevezett zaklató követés esetén 1997 óta kérhető távoltartás, amely azonnali rendőri segítség, így a helyszínre érve gyors és hatékony, azonban kétségtelenül ideiglenes megoldást jelenthet a bántalmazó és a bántalmazott közötti konfliktus feloldására. Tóth Andrea Noémi a magyar és az osztrák jogintézményeket vizsgáló tanulmányában kiemelte, hogy a családon belüli erőszak elleni küzdelem során a magyar jogalkotó mindvégig az osztrák rendszert tekintette mintának, melyet nemcsak a földrajzi közelség, és a jogrend hasonlósága indokolt, hanem az is, hogy a szomszédos országban ez már több mint húsz éve sikerrel és hatékonyan múködik. ${ }^{24}$ Ausztriában a családi konfliktus helyszínére érkező rendőrök speciális (pszichológiai és kommunikációs) felkészítésben részesültek, a távoltartási időszak alatt pedig a rendőrség feladata a családdal foglalkozó szolgálatok felé történő jelzés, valamint a folyamatos kapcsolattartás a női, gyermekvédelmi és férfiak számára elérhető tanácsadó szervezetekkel. ${ }^{25}$

Rosa Logar témában készült összeállítása számos előírást ismertet, és már a bevezetőben kitér arra, hogy az erőszakkal szembeni védelemhez kapcsolódó törvények egyfajta láncolatot képeznek, fokozatosan hozták meg azon intézkedési lehetőségek széles skáláját, amelyekkel biztosítani vélhető az áldozatok fokozottabb védelme. Ausztriában minden ott tartózkodó személy jogosult az erőszakkal szembeni védelemre, származástól és állampolgárságtól függetlenül, ezért az osztrák rendőrség számára az erőszak esetén való sürgősségi beavatkozás kötelező előírás, melynek során gondoskodnak a veszélyeztető személy azonnali kiutasításáról annak érdekében, hogy az áldozat az otthonában maradhasson, és elsődlegesen így kaphasson védelmet. A saját lakókörnyezetében való erőszaktól mentes életre mindenkinek joga van, ezért Ausztriában közvetlen rendőri védelem van érvényben, ${ }^{26}$ erre vonatkozó jogintézményük a belépési tilalom. A tulajdoni viszonyoknak Ausztriában sincs jelentősége, így irreleváns, hogy ki az ingatlan tulajdonosa, a lakásból kiutasítható minden olyan személyt, aki veszélyt jelent másokra, így természetesen a tulajdonos is. A rendőrségnek a lakás kulcsait azonnali intézkedésként el kell vennie a veszélyeztető személytől, azonban a személyes használathoz legszükségesebb tárgyakat az érintett magával viheti. A belépési tilalmat kizárólag a

\footnotetext{
24 TÓTH, 2013.

${ }^{25}$ FELLEGI, 2007. 2.o.

26 SiCHERHEITSPOLIZEIGESETZ (SPG) 38A $\int$
} 
hatóságok szüntethetik meg, ez azonban nagyon ritkán fordul elő. Amennyiben a hatóságok annak lejárta előtt hatályon kívül helyezik a döntést, az áldozatot erről haladéktalanul értesíteniük kell. ${ }^{27}$

Az osztrák jogalkotás a magyar távoltartási törvény [hozzátartozók közötti erôszak miatt alkalmazható távoltartásról szóló 2009. évi LXXII. törvény, (a továbbiakban: Hketv) bevezetése kapcsán több vonatkozásban is mintaként szerepelt. Az egyes rendelkezéseinek alkotmányellenességével foglalkozó $\mathrm{AB}$ határozatban a magyar Alkotmánybíróság is pozitív példaként említette a fenti osztrák szabályozást, mely megoldás lényegében a Duluth-modell szerint felépített megelőzési rendszeren alapul, abban a civil szervezetek, a rendőrség, a családjogi bíróság és a büntető igazságszolgáltatás egyaránt szerephez jutnak. ${ }^{28}$

Álláspontom szerint az ausztriai szabályozás lényegi pontja az alapvetően két hétig tartó és a bíróság által meghosszabbítható belépési és megközelítési tilalom betartásának rendőrség általi kötelező ellenőrzése (alkalmazásának első három napja során legalább egyszer), de egyébként a rendőrségi kiszállás (helyszíni intézkedés) az elrendelésének nem feltétele. Ezekre az intézkedésekre akkor is sor kerülhet, ha az áldozat megtörtént erôszak miatt bejelentést tesz, és ugyan további erôszaktól tart, de a rendőrséget erről nem értesíti. Ideiglenes intézkedés alapvetően testi erőszak miatt kérhető, de lehetőség biztosított azon esetekben is, amikor az áldozat irányába csupán az ezzel való fenyegetés mutatkozik, és a fenyegetővel való együttélés nem tartható fenn. Lényeges hangsúlyozni, hogy a szomszédos országban lelki erőszak esetén is kérelmezhető távoltartás, minden olyan személy részesülhet védelemben, aki lakóterében és/vagy személyes életterében erőszakot szenved el. A rokoni kapcsolat megléte veszélyeztető és veszélyeztetett között nem feltétele az ideiglenes intézkedésnek.

Éles különbségnek ítélem, hogy az osztrák törvény veszélyeztető és veszélyeztetett fogalmat használ, míg a magyar Hketv. bántalmazót és bántalmazottat definiál. A büntetőjogi értelemben vett veszély a sérelem bekövetkezésének csupán a lehetőségét jelenti, ${ }^{29}$ míg bántalmazóbántalmazott viszonyrendszerében - a szóhasználatból eredően - ez már megtörtént cselekvésen alapul, tehát nemcsak egy jövőre vetített feltételezést sugall. Úgyszintén kiemelésre méltó, hogy Ausztriában ingyenes tanácsadás és támogatás történik az intervenciós (német elnevezés: Interventionsstellen) és

27 WiENER INTERVENTIONSTELLE GEGEN GEWALT IN DER FAMILIE, 2017.

28 53/2009. (V.6.) AB HATÁROZAT

29 1/2015. BÜNTETŐ ELVI HATÁROZAT 
a védelmi központokban (német elnevezés: Gewaltschutzzentren). Belépési tilalom elrendelése esetén a területileg illetékes szervek veszik fel a kapcsolatot a sértettel (és nem fordítva) amiatt, hogy felkínálják számára az ingyenes tanácsadás és támogatás lehetőségét, amely véleményem szerint rendkívül méltányos megoldásnak tekinthető.

Ausztria vonatkozásában végül érdemes szemügyre venni, milyen álláspontot képvisel a Bécsi Intervenciós Központ a családon belüli erőszak tekintetében. A hivatal rögzítette, hogy az erőszak sokféle formában fordul elő az egyes kapcsolatokban, melynek kérdése korosztálytól, életkortól és kultúrától függ; fizikai, mentális és szexuális szinten egyaránt megjelenhet, amelyet a hatalom gyakorlásának, a hatalommal való visszaélésnek, illetve a bántalmazás vagy kényszerítés bármilyen formájaként kell érteni. A hivatal egyebek mellett rávilágít arra a sokáig elhanyagolt tényre, miszerint az anya ellen elkövetett, általa átélt erőszak akkor is veszélyezteti a gyermekeket, ha „csak” tanúi az erőszakos cselekedeteknek. ${ }^{30}$ Hivatalos álláspontjukat nemzetközi tanulmányokkal támasztják alá, melyek alapján az anyákkal való rossz bánásmód szorosan összefügg a gyermekek sorsával, mert a kiskorúak nemcsak meglévő kapcsolatokban, hanem az elszakadás alatt és után is áldozataivá válnak a történteknek. ${ }^{31} \mathrm{Az}$ összehangolt munka elmaradhatatlan voltára utal az 1993-ban alapított osztrák hálózat is, amely egyetlen platformként fogja össze a tanácsadó intézmények együttmúködését; célja az erőszak csökkentése, az észlelési arány növelése, a beavatkozás hatékonysága, illetve a jogtudatosság növelése. Ausztriában felismerték azt, hogy kizárólag a különféle területek összehangolása teszi lehetővé az erôszak megelőzésére irányuló koncepciók és konstruktív modellek kidolgozását, ${ }^{32}$ tematikus területei közé tartozik a gyermekek és a nôk elleni erőszak mellett a fiatalok elleni/közötti, az idősek, illetve a férfiak elleni családon belüli erőszak is. ${ }^{33}$ Példaértékűnek tekinthető a 2012. január 1. napján hatályba lépett szövetségi gyermekvédelmi törvény is (rövidítve: BKiSchG), mert egy kifejezetten aktív tevékenységre kötelez, és amelyben a megelőzés és a beavatkozás két pillérre épül: a gyermek jóléte érdekében erősíti az összes szereplőt (szülő, gyermekorvos, szülésznő, ifjúsági hivatal, családjogi bíróság

\footnotetext{
30 WienER InterVENTIONSSTELLE. GEGEN GEWALt IN DER FAMILIE. GEWALT GEGEN FRAUEN UND KINDER

31 WiENER INTERVENTIONSSTELLE. KINDER ALS OPFER VON GEWALT

32 Bundeskanzleramt. PlattForm GEGEN Die GEWALt IN DER FAMILIE

33 BundESMINISTERIUM FÜR ARBEIT, FAMILIE UND JUGEND,SEKTION FAMILIE UND JUGEND
} 
stb.), illetve tevőleges védelmet is jelent egyben. Jogszabályban garantálják a korai segítséget, a megbízható gyermekvédelmi hálózatokat, nagyobb cselekvési és jogbiztonságot nyertek a gyermekvédelemben részt vevők (hidat építettek az ifjúsági jóléti hivatalok és az úgynevezett szakmai titoktartók között), megerősítették a gyermekek és a fiatalok cselekvési jogát, illetve kötelezően előírták a folyamatos minőségfejlesztést. ${ }^{34}$

\subsection{SZLOVÁKIA}

A Magyarországgal úgyszintén szomszédos Szlovákiában ${ }^{35}$ a „jogforrás” fogalmát három értelemben használják: anyagi jogi, ismeretelméleti (a jogtudomány forrásai) és hivatalos értelemben. A jogi normák létrejötte és kifejeződési formája szerint hagyományosan több jogforrástípust különböztetnek meg, amelyek a jogszokás, a jogeset (esetjog), a normatív jogi aktusok, a normatív szerződések, az általános jogelvek, az ésszerű gondolkodás, a kortárs könyvek, jogi szakirodalom és szakértői jelentések, valamint ide tartoznak a nemzetközi szerződések, ha azokat jogszerűen becikkelyezték a Szlovák Köztársaság jogrendjébe. A normák hierarchiája a szlovák jogrendszer egyik alapelveként múködik, amelyek joggyakorlatban és a végrehajtásban elfoglalt helyének megértése a törvényesség szempontjából kiemelten fontos. Nem egyszerủen logikai sorrend vagy alárendeltség kérdése, hanem azt összefüggésben tartják a legitim hatalom egész kérdésével, így magában foglalja a kategorikus imperatívuszt is. A jogszabályi hierarchia Szlovákiában is azon tulajdonságra utal, amely szerint a magasabban elhelyezkedő rendelkezés az alacsonyabb szintủ normát alárendeli, így a magasabb szintû értelemszerűen hatálytalaníthatja ezt. Szlovákiában az elsődleges jogszabályok mindig törvények, az alkotmányos törvények pedig mindig elsődlegesek. ${ }^{36}$

Szlovákiában - hasonlóan Magyarországhoz - sui generis bűncselekményi tényállásban nyert elhelyezést a családi erőszak, elnevezésében is ugyanaz, de a szabályozás tartalmában eltérő. A szlovák Büntető Törvénykönyv (szlovák elnevezés: Trestny Zákon Tt. 300/2005) ${ }^{37}$ a 208. \-ban szerepelteti a kapcsolati erőszak bủncselekményi tényállását, mely

\footnotetext{
${ }^{34}$ GESETZ ZUR STÄRKUNG EINES AKTIVEN SCHUTZES VON KINDERN UND JUGENDLICHEN (Bundeskinderschutzgesetz).

35 Szlovákia 2004. május 1. napján csatlakozott az Európai Unióhoz.

${ }^{36}$ European JusticE. Szlovákia.

37 TRESTNY ZÁKON TT. 300/2005.
} 
hazánkhoz hasonlóan úgyszintén a család elleni és a gyermekek érdekét sértő bűncselekmények fejezetében ${ }^{38}$ nyert elhelyezést, azonban a 2019. augusztus 1. napjától hatályos új szlovák büntető törvénykönyv a hazaihoz viszonyítva jóval szigorúbbnak tekinthetô a kérdésben.

A tényállás alapján, aki hozzátartozója, illetve gondozása és nevelése alatt álló személy sérelmére fizikai és pszichikai bántalmazást követ el azáltal, hogy

a) veréssel, rugdalással, ütlegeléssel, különböző sebek és égési sérülések okozásával, megalázó és megvető magatartás tanúsításával, folyamatos követéssel, fenyegetéssel, félelem és stressz okozásával, erőszakos elszigeteléssel, érzelmi zsarolással vagy egyéb magatartás tanúsításával veszélyezteti annak fizikai és pszichikai épségét és egészségét, illetve korlátozza biztonságát,

b) indokolatlanul elvonja az élelmet, a pihenést és az alvást, illetve a szükséges gondoskodást, a ruházatot, a tisztálkodás lehetőségét, az egészségügyi gondoskodást, a lakhatáshoz, a művelődéshez és a neveléshez füződő jogát,

c) koldulásra vagy korához, illetve egészségi állapotához képest aránytalan fizikai vagy pszichikai megterheléssel, illetve az egészségromlás veszélyével járó tevékenység folyamatos végzésére kényszeríti,

d) egészségromlás okozására alkalmas anyagok hatásának teszi ki, vagy

e) indokolatlanul a közös gazdálkodás körébe vagy közös vagyonba tartozó anyagi javakat von el,

három évtől nyolc évig terjedô szabadságvesztéssel büntetendő.

Ezen büntetés érvényes arra is, aki a fentiekben foglalt cselekményhez hasonló cselekményt valósít meg, jóllehet hasonló cselekmény miatt az eltelt tizenkét hónap során büntetve volt. Minősített esetként határozza meg törvény, ha a fent írt cselekményt súlyos egészségkárosodást vagy halált okozva, különös indítékból, az eltelt huszonnégy hónap során ilyen cselekmény miatt elítélt vagy ilyen cselekmény miatt büntetését letöltött visszaesőként vagy súlyosabban minôsülő módon követik el (héttől tizenöt évig terjedő szabadságvesztés), illetve több személy sérelmére elkövetett súlyos egészségkárosítást vagy halált okozva követik el (tizenöttől huszonöt évig terjedő vagy életfogytig tartó szabadságvesztés).

38 Szlovák Btk. Harmadik Fejezet. A család elleni és a gyermekek érdekét sértő bűncselekmények. 204-211. §: kettős házasság, kiskorú felügyeletének elhanyagolása, kiskorú veszélyeztetése, tartási kötelezettség elmulasztása, kapcsolati erőszak, kiskorú elhelyezésének megváltoztatása, kiskorú erkölcsi fejlődésének veszélyeztetése. 
A büntetőjogi kódex rendelkezéséből látható, hogy Ausztriával és Magyarországgal ellentétben a bűncselekményi szabályozáshoz - vagy annak egy részéhez - nem kapcsolódik szubszidiaritás, a szlovák jogalkotó tehát nem teremtett a bűncselekmény számára alsóbb rendű, kisegítő jelleget, így a tényállási elemek megvalósulása esetén nem kell vizsgálni egyéb más bűncselekmények megtörténtét sem.

A szlovák Btk. az emberi méltóság elleni bűncselekmények között tárgyalja a nemi élet szabadsága és a nemi erkölcs elleni bűncselekmények körébe tartozó magatartásokat, így a szexuális erôszakot, kényszerítést és visszaélést, melyek vonatkozásában a szexuális erőszaknál és a kényszerítésnél utal a bűncselekmény passzív alanyaként „,védett személy”re, kifejezett sérteti életkor megjelölése a szexuális visszaélés tényállásában jelenik meg. Számos helyen tartalmazza a törvény minősített esetként a „védett személy” sérelmére történő elkövetést, melynek tartalmát a 139. \ban definiálja, ugyanakkor erre a fokozott védelemre nem kerülhet sor, ha a bűncselekmény elkövetésére nem a védett személy pozíciójával, állapotával vagy korával összefüggésben került sor. A családon belüli erőszak kapcsán rögzítendő, hogy Szlovákiában törvény értelmében védett személynek minősül egyebek mellett a gyermek, a várandós nő, a hozzátartozó, a rászoruló, időskorú, betegségben szenvedő fél.

A szexuális erőszak alapesetben öt évtől tíz évig terjedő szabadságvesztéssel büntetendő a felső szomszédos országban, és az követi el, aki erőszakkal, illetve az élet vagy testi épség ellen irányuló közvetlen fenyegetéssel nőt közösülésre kényszerít, vagy védekezésre képtelen állapotát szexuális cselekményre használja fel. A szexuális erőszak súlyosabb esetekben héttől tizenöt évig ${ }^{39}$, tizenöttől húsz évig ${ }^{40}$, illetve húsztól huszonöt évig ${ }^{41}$ terjedhet. A szexuális kényszerítés bűncselekményét az követi el, aki erőszakkal, illetve közvetlen fenyegetéssel mást orális vagy anális érintkezésre, vagy egyéb szexuális praktikára kényszerít, valamint védekezésre képtelen állapotát ilyen cselekményre használja fel (öttől tíz évig terjedő szabadságvesztéssel büntetendő), míg a minősített esetekben a szexuális erőszaknál megjelölt büntetési tételkeretek és elkövetési módok köszönnek vissza. A szlovák jogalkotó a hazainál magasabb életkorban húzta meg a szexuális visszaélés határát azzal, hogy azon személyt bünteti,

39 Súlyosabban minősülő módon, védett személy sérelmére, különös indítékból, fogvatartott vagy szabadságvesztés büntetését töltő nő sérelmére.

40 Súlyos egészségkárosodást okozva.

${ }^{41}$ Halált okozva vagy válsághelyzetben. 
aki tizenötödik életévét be nem töltött személlyel közösül, vagy aki ilyen személy sérelmére egyéb módon szexuális visszaélést követ el (háromtól tíz évig terjedő szabadságvesztés). A bűncselekmény minősített esetéért héttől tizenkét évig, ${ }^{42}$ tizenkét évtől tizenöt évig, ${ }^{43}$ illetőleg tizenöttől húsz évig ${ }^{44}$ terjedő szabadságvesztéssel büntetendőséget rögzített a jogalkotó.

Szlovákiában kiemelt figyelem övezi a családon belüli erőszak gyermekáldozatait, ezért többek között oktatási segédanyagban rögzítették a pedagógusok számára, hogy kötelesek olyan feltételeket teremteni, amelyek biztosítják a gyermekek fejlődését, biztonságát, egészségük védelmét, illetve megelőzik a szocio-patológiai jelenségek kialakulását. Bűnmegelőzési és áldozatvédelmi szempontból igen lényegesnek ítélem azon kijelentés rögzítését, miszerint az intézményeknek aktív módon, konkrétan, kézzel foghatóan kell tenniük a gyermek védelme érdekében, kötelesek folyamatosan figyelemmel kísérni a viselkedését, annak változásait, egészséges személyiségfejlődésének veszélyeztetése esetén pedig problémái megoldásához azonnali védelmet kap az iskola vezetésének bevonásával. Úgyszintén követendő példaként tartható számon a gyermekjogokról szóló információkhoz való hozzáférés biztosítása, ami különösen a gyermekek elleni erőszakot, és a megelőzés, a segítség lehetséges formáit juttatja el ezen korosztályhoz. ${ }^{45}$ Szlovákiában és Ausztriában is tevékenykedik a közigazgatási struktúra tekintetében specialitásnak számító, és először 1981ben Norvégiában megjelent gyermekjogi ombudsman, elnevezése a skandináv eredetű „ombud” (nagykövet, képviselő, hírnök) szóból származik. ${ }^{46}$ Szlovákia mindegyik megyéjében található több olyan szervezet, akik speciálisan a bántalmazottaknak nyújtanak segítséget, legtöbbjük krízisközpontot is múködtet, ahol szabad szobát, ingyenes jogi és/vagy pszichológiai tanácsadást kaphatnak az otthonról elmenekülni kénytelenek, továbbá a telefonos segélyvonal némelyike éjjel-nappal a sértettek rendelkezésére áll. ${ }^{47}$

\footnotetext{
42 Súlyosabban minősülő módon, védett személy sérelmére, vagy különös indítékból.

43 Súlyos egészségkárosodást okozva.

${ }^{44}$ Halált okozva, vagy válsághelyzetben.

45 BURAJOVÁ-ČINČUROVÁ, 2016. 37. o.

46 KÖRNYEI, 2009. 55-56. o.

47 LENGYEL, 2015.
} 


\section{KONKLÚZIÓ}

Tanulmányom bevezető részében a jelenségre adott választ illetően mérföldkőnek számító Isztambuli Egyezmény „születését”, és annak egyes tagállamokra gyakorolt hatását ismertettem, mely a büntetőjogi szabályozással kölcsönhatásban az egyes országok törvénykönyveiben vált valósággá. Írásom további részében a magyar büntetőjog történetében elsőként megjelenő, tehát nóvumnak számító önálló bűncselekményi tényállás lényegi sajátosságait ragadtam meg, majd két szomszédos országba kalauzoltam az olvasót, melynek keretében Ausztria és Szlovákia joganyagát, illetve családvédelmi törekvéseit állítottam fókuszba.

A jogösszehasonlítások nagyon kis szeletét láthatjuk jelen írás által, mégis úgy gondolom, hogy az Isztambuli Egyezmény - és más, úgyszintén fontos nemzetközi dokumentumok - alappillérét jelenthetik az egyes tagállamok büntetőjogi szabályozásának azon esetekben is, amennyiben az aláirást még nem követte ratifikáció, hangsúlyozva természetesen az egyéb intézkedések, intézményrendszer és feltételek szükségességét is. Magyarország érdemi lépései mellett a jelenség szélesebb skálán történő megismeréséhez a nemzetközi törekvések, és más államok szabályozási koncepcióinak áttekintése éppúgy fontosak, jelen tanulmányban ebből merítettem.

\section{FELHASZNÁLT IRODALOM}

Mgr. Barbora Burajová - Mgr. SÁra ČinČurová (2016): A nők elleni erőszak és a családon belüli erőszak. Oktatási segédanyag pedagógusok és oktatásügyben dolgozó szakemberek számára. Bratislava/Pozsony

Elérhetô: https://www.gender.gov.sk/zastavmenasilie/files/2016/02/Anok-elleni-eroszak-es-a-csaladon-beluli-eroszak-.pdf

(Letöltve: 2020. február 26.)

FELLEGI BORBÁLA (2007): Büntetőügyi mediáció, fiatalkorúak elkövetése, családon belüli erőszak - Mit kezd mindezen kérdésekkel az osztrák intézményrendszer? Beszámoló a Család, Gyermek, Ifjúság Egyesület AGIS programján belül megvalósuló bécsi tanulmányútról. Elérhető: https://www.foresee.hu/uploads/tx abdownloads/files/AGIS Becs b eszamolo 2-1.pdf (Letöltve: 2020. február 11.)

Grevio (2017): Grevio Baseline Evaluation Report Austria. Elérhető: https://rm.coe.int/grevio-report-austria-1st-evaluation/1680759619 
(Letöltve: 2020. február 11.)

GREviO (2016): Grevio First Country Report Austria. Elérhető: https://rm.coe.int/16806ee8b2 (Letöltve: 2020. február 11.)

IGAZSÁGÜGYI MINISZTÉRIUM (2019), Jelentés a Kormány részére a győri kettős gyermekgyilkosság igazságügyi vizsgálatának eredményérôl.

Elérhetô:

https://www.kormany.hu/download/5/1f/b1000/Jelent $\%$ C3\%A9s gy \%C5\%91ri gyilkoss \%C3\%A1g 2019dec.pdf (Letöltve: 2020. február 11.)

KÖRNYEI ÁGNES (2009): Skandinávia mint „normatív éllovas” a gyermekjogok terén. Külügyi Szemle 2009/4. szám. Elérhető: https://kki.hu/assets/upload/Kulugyi Szemle 200904 Skandinevia mint normate.pdf (Letöltve: 2020. március 12.)

LAJTÁr ISTVÁN (2013): A gyermekek érdekét sértő és a család elleni bűncselekmények. Új Btk. Kommentár 4. kötet. Különös rész. XX. fejezet In Polt Péter főszerk.: Nemzeti Közszolgálati és Tankönyv Kiadó.

LENGYEL DiAnA (2015): Erőszak a családban. Hova forduljunk? Körkép.SK. 2015.03.26.

Elérhetô:

http://www.korkep.sk/cikkek/mindennapjaink/2015/03/26/eroszak-acsaladban-hova-forduljunk (Letöltve: 2020. február 10.)

RÁCZ ANDREA (2016): Gyermekvédelem a változás-elmélet tükrében. Metszetek. 2016/4. szám. Elérhető: http://metszetek.unideb.hu/files/metszetek $\% 202016 \quad 4 \quad 10$ racz.pdf

(Letöltve: 2020. február 10.) DOI azonosító: 10.18392/METSZ/2016/4/10 TÓTH ANDREA NOÉMI (2013): Távoltartás osztrák mintára?

Debreceni Jogi Műhely, 2013/3. szám. Elérhetô: http://www.debrecenijogimuhely.hu/archivum/3 2013/tavoltartas oszt rak mintara/\# edn6 (Letöltve: 2020. február 15.) DOI azonosító: $10.24169 / \mathrm{DJM} / 2013 / 3 / 7$

Wiener InTERVENTIONSTELLE GEGEN GEWAlt IN DER FAMilie - Bécsi Intervenciós Központ a Családon Belüli Erőszak Ellen (2017) Rosa Logar: Védelem és segítség erőszak áldozatainak. Elérhető: https://www.interventionsstellewien.at/download/?id=gewaltschutzfolder ung.pdf (Letöltve: 2020. február 15.) 
Internetes hivatkozások

DipPOLD ÁDÁM (2020): Karantén idején világszerte tombol a családon belüli erőszak. Elérhető: https://qubit.hu/2020/03/28/karanten-idejenvilagszerte-tombol-a-csaladon-beluli-eroszak (Letöltve: 2020. március 29.)

GESETZ ZUR STÄRKUNG EINES AKTIVEN SCHUTZES VON KINDERN UND JUGENDLICHEN (Bundeskinderschutzgesetz) Elérhető: https://www.bmfsfj.de/bmfsfj/aktuelles/alle-meldungen/gesetz-zurstaerkung-eines-aktiven-schutzes-von-kindern-und-jugendlichen-bundeskinderschutzgesetz$\angle 78126 \% 3$ Fview $\% 3$ DDEFAULT\&usg=ALkJrhhAaVoaPTkRWh59Euu gME wNHBQKQ (Letöltve: 2020. február 10.)

Wiener Interventionsstelle: Gegen Gewalt in der Familie. Gewalt gegen Frauen und Kinder.

Elérhetô: $\quad$ https://www.interventionsstelle-wien.at/gewalt-gegen-frauenund-kinder (Letöltve: 2020. február 15.)

WiENER INTERVENTIONSSTELLE: Kinder ALS OPfER VON GEWALT. Elérhető: https://www.interventionsstelle-wien.at/kinder-als-opfer-vongewalt (Letöltve: 2020. február 15.)

ISTANBUL CONVENTION ACTION AGAINST VIOLENCE AGAINST WOMEN AND DOMESTIC VIOLENCE. Elérhető: https://www.coe.int/en/web/istanbul-convention/historicalbackground (Letöltve: 2020. február 15.)

CHART OF SIGNATURES AND RATIFICATIONS OF TREATY 210 COUNCIL OF EUROPE CONVENTION ON PREVENTING AND COMBATING VIOLENCE AGAINST WOMEN AND DOMESTIC VIOLENCE. Elérhető: https://www.coe.int/en/web/conventions/full-list/Lconventions/treaty/210/signatures (Letöltve: 2020. február 15.)

IGAZSÁGÜGYI MINISZTÉRIUM.

Elérhetô: https://www.kormany.hu/hu/igazsagugyi-miniszterium/hirek/a-gyorikettos-gyermekgyilkossagrol-keszult-jelentes (Letöltve: 2020. február 11.)

EUROPEAN JUSTICE. Ausztria. Elérhető: https://ejustice.europa.eu/content member state law-6-at-maximizeMShu.do?member=1 (Letöltve: 2020. február 10.)

EUROPEAN JUSTICE. Szlovákia. Elérhető: https://ejustice.europa.eu/content member state law-6-sk-hu.do?member=1 (Letöltve: 2020. február 10.) 
SZÉKELY HíRMONDÓ (2020): Karantén idején világszerte tombol a családon belüli erőszak. Elérhető: https://www.hirmondo.ro/tudomany/karanten-idejen-vilagszertetombol-az-eroszak/(Letöltve: 2020. március 29.)

THE GUARDIAN: Lockdowns around the world bring rise in domestic violence Elérhetô: https://www.theguardian.com/society/2020/mar/28/lockdownsworld-rise-domestic-violence (Letöltve: 2020. március 29.)

Joganyagok

2012. ÉVI C. TÖRVÉNY A BÜNTETŐ TÖRVÉNYKÖNYVRŐL. 1/2015. BÜNTETŐ ELVI HATÁROZAT 31. pont.

17/2017. SZ. BÜNTETŐ ELVI HATÁROZAT. 53/2009. (V.6.) AB HATÁROZAT III.2.2. pont. https://www.jusline.at/gesetz/stgb/gesamt https://www.jusline.at/gesetzeskommentare/456492181 https://www.jusline.at/gesetz/spg Trestny Zákon Tt. 300/2005. Elérhetô: https://www.torvenytar.sk/zakon-547 (Letöltve: 2020. február 3.) 